\title{
Hubungan Nilai D-Dimer Dan LDL Kolesterol Pada Penderita Stroke Iskemik Di RSUD BUDHI ASIH
}

Jakarta Timur

\author{
Yune Yohana $^{1)}$, *Cahyawati Rahayu ${ }^{2)}$, Bella Sely Destriana ${ }^{2)}$ \\ ${ }^{1}$ RS PMI Bogor \\ ${ }^{2}$ Program Studi Analis Kesehatan, Fakultas Kesehatan, Universitas Mohammad Husni Thamrin \\ Correspondence author:Cahyawati Rahayu, rahayucahyawati@gmail.com, Jakarta, Indonesia
}

\begin{abstract}
ABSTRAK
Stroke mengacu kepada setiap gangguan neurologik mendadak yang terjadi akibat terhentinya aliran darah melalui sistem suplai arteri otak. Etiologi utama yang menimbulkan penyumbatan adalah aterosklerosis. LDL sering dihubungkan dengan aterosklerosis. Aterosklerosis ditandai dengan adanya penumpukan plak pada tunika intima pembuluh darah arteri. D-dimer merupakan suatu produk degenerasi fibrin yang menunjukan adanya trombosis ataupun fibrinolisis. Penelitian ini bertujuan untuk mengetahui hubungan nilai D-dimer dan LDL kolesterol pada penderita Stroke iskemik di RSUD Budhi Asih Jakarta Timur. Desain penelitian ini adalah cross sectional (potong lintang). Sebanyak seratus sepuluh pasien Stroke iskemik fase akut yang diambil menggunakan data sekunder berupa rekam medis di RSUD Budhi Asih Jakarta Timur. Berdasarkan jenis kelamin, didapatkan pria sebesar 56,4\% dan wanita sebesar 43,6\%. Berdasarkan kelompok usia, persentase tertinggi pada kelompok usia 55-64 tahun sebanyak 35,5\%. Berdasarkan nilai normal, kadar LDL abnormal sebanyak 69\% dengan D-dimer abnormal sebanyak 77\%. Sedangkan kadar LDL normal sebanyak $31 \%$ dengan D-dimer normal sebanyak 23\%. Berdasarkan uji korelasi Pearson didapatkan hasil signifikansi dengan nilai 0,00 $(\mathrm{p}<0,05)$ serta nilai $\mathrm{r}(0,840)$ yang berarti terdapat hubungan antara kadar LDL kolesterol dengan kadar D-dimer pada pasien Stroke iskemik di RSUD Budhi Asih Jakarta Timur. Hasil penelitian dapat disimpulkan bahwa pemeriksaan LDL kolesterol dan D-dimer dapat digunakan sebagai penunjang prognosis pada penderita Stroke iskemik.
\end{abstract}

Kata kunci

: D-dimer, LDL, Stroke iskemik.

\begin{abstract}
Stroke refers to any sudden neurologic disorder that occurs as a result of stopping blood flow through the arterial supply system of the brain. The main etiology that causes blockage is atherosclerosis. LDL is often associated with atherosclerosis. Atherosclerosis is characterized by the buildup of plaque on the intima of the arteries. D-dimer is a fibrin degeneration product that indicates thrombosis or fibrinolysis. This study aims to determine the relationship between D-dimer and LDL cholesterol values in ischemic stroke patients at Budhi Asih Hospital, East Jakarta.

The design of this study was cross sectional (cross-sectional). A total of one hundred and ten acute phase ischemic stroke patients were taken using secondary data in the form of medical records at Budhi Asih Hospital, East Jakarta. Based on gender, it was found that men were $56.4 \%$ and women were $43.6 \%$. Based on the age group, the highest percentage was in the 55-64 years age group as much as 35.5\%. Based on normal values, abnormal LDL levels were 69\% with D-dimers abnormal as much as $77 \%$. Meanwhile, normal LDL levels were $31 \%$ and normal D-dimers were $23 \%$. Based on the Pearson correlation test, a significance value was obtained with a value of $0.00(p<0.05)$ and a value of $r(0.840)$, which means that there is a relationship between $L D L$ cholesterol levels and D-dimer levels in ischemic stroke patients at Budhi Asih Hospital, East Jakarta.

The results of the study concluded that the examination of LDL cholesterol and D-dimers could be used as prognosis support in ischemic stroke patients.
\end{abstract}

Key words: D-dimer, LDL, ischemic stroke. 


\section{PENDAHULUAN}

Stroke atau dikenal dengan penyakit serebrovaskuler, merupakan penyakit neurologik yang terjadi karena gangguan suplai darah menuju ke otak. Ada dua tipe stroke yaitu stroke hemoragik dan stroke iskemik. Stroke iskemik banyak disebabkan karena trombotik atau sumbatan emboli, sedangkan stroke hemoragik disebabkan oleh perdarahan akibat pecahnya pembuluh darah di suatu bagian otak (Wayunah \& Saefulloh, 2018).

Menurut taksiran World Health Organization (WHO), sebanyak 20,5 juta jiwa di dunia sudah terjangkit stroke tahun 2011. Dari jumlah tersebut 5,5 juta jiwa telah meninggal dunia. Penyakit darah tinggi atau hipertensi menyumbangkan 17,5 juta kasus stroke di dunia. Sebanyak $28,5 \%$ penderita meninggal dunia dan sisanya menderita kelumpuhan sebagian atau total. Hanya $15 \%$ saja yang dapat sembuh total dari serangan stroke dan kecacatan (LF Nasution, 2013).

Stroke merupakan penyakit yang menempati urutan ketiga terbanyak setelah penyakit jantung dan kanker, serta merupakan penyakit penyebab kecacatan tertinggi di dunia. Dari seluruh penderita stroke di Indonesia, stroke iskemik merupakan jenis yang paling banyak diderita yaitu sebesar 52,9\%, diikuti secara berurutan oleh perdarahan intraserebral, emboli dan perdarahan subaraknoid dengan angka kejadian masing-masingnya sebesar 38,5\%, 7,2\% dan 1,4\% (Dinata, Safrita, \& Sastri, 2013).

Faktor yang dapat menimbulkan stroke dibedakan menjadi faktor risiko yang tidak dapat diubah dan faktor risiko yang dapat diubah. Faktor risiko yang tidak dapat diubah diantaranya peningkatan usia dan jenis kelamin. Faktor risiko yang dapat diubah antara lain hipertensi, diabetes melitus dan dislipidemia (Dinata et al., 2013).

Stroke iskemik adalah tanda klinis disfungsi atau kerusakan jaringan otak yang disebabkan kurangnya aliran darah ke otak sehingga mengganggu kebutuhan darah dan oksigen di otak (Kabi, Tumewah, \& Kembuan, 2015). Peningkatan risiko stroke dihubungkan dengan Low Density Lipoprotein (LDL) yang tinggi, kolesterol High Density Lipoprotein (HDL) yang rendah serta rasio kolesterol LDL dan HDL yang tinggi akan diperkuat bila ada faktor risiko stroke yang lain (Agusti, Yacob, \& Fridayenti, 2014). 
Diagnosis stroke iskemik didasarkan pada riwayat penyakit anamnesis, pemeriksaan fisik dan pemeriksaan penunjang yang meliputi pemeriksaan radiologis dan laboratoris. Pemeriksaan laboratoris didapatkan dari pemeriksaan hematologi lengkap, profil lipid, kadar gula darah, elektrolit, ureum, kreatinin, enzim jantung, analisa gas darah, protrombin time (PT) dan activated tromboplastin time (aPTT), kadar fibrinogen serta D-dimer (Widjaja, 2010).

Pada pemeriksaan laboratoris kadar LDL yang tinggi akan menyebabkan terbentuknya plak aterosklerosis yang akan meningkatkan resiko terjadinya stroke iskemik. Sementara kadar LDL yang rendah juga akan meningkatkan resiko terjadinya stroke hemoragik yang berhubungan dengan perburukan neurologis awal dan kematian (Hasibuan, Fitri, Surbakti, \& Rambe, 2015).

Beberapa penelitian terdahulu, ditemukan bahwa kadar D-dimer juga meningkat pada fase akut stroke. Ada pula yang menyebutkan bahwa kadar D-dimer plasma (bersama dengan tekanan tekanan darah arteri rata-rata) merupakan prediktor independen perkembangan stroke iskemik (Widjaja, 2010).

Jumlah kolesterol LDL (High Density Lipoprotein) yang berlebih di dalam darah akan diendapkan pada dinding pembuluh darah dan membentuk bekuan yang dapat menyumbat pembuluh darah sehingga menyebabkan terjadinya aterosklerosis. Pemeriksaan kadar D-dimer dapat digunakan untuk penilaian awal sub tipe stroke iskemik apakah kardioemboli, aterotrombotik atau lakunar. Peningkatan kadar D-dimer mempunyai hubungan linear pada pasien stroke iskemik (Darmawaty et al., 2011).

Berdasarkan latar belakang tersebut, peneliti tertarik untuk melakukan penelitian terkait hubungan nilai D-dimer dan LDL kolesterol pada penderita Stroke iskemik di RSUD Budhi Asih Jakarta Timur.

\section{METODE}

Di Laboratorium RSUD Budhi Asih. Kemudian dilakukan penelitian pada bulan Agustus 2019. Populasi penelitian ini adalah pasien Stroke iskemik dalam fase akut yang melakukan pemeriksaan di Laboratorium RSUD Budhi Asih. Sampel penelitian ini adalah pasien Stroke iskemik dalam fase akut yang melakukan pemeriksaan D-dimer dan LDL kolesterol di Laboratorium RSUD Budhi Asih periode Januari 2017-Desember 2018. Memilih medical record pasien Stroke iskemik fase akut yang melakukan pemeriksaan D-dimer dan kolesterol LDL di bagian rekam medis. Mencatat nama dan medical record pasien Stroke iskemik fase akut yang melakukan pemeriksaan D-dimer dan kolesterol 
LDL. pemeriksaan D-dimer dan LDL kolesterol pada penyakit Stroke iskemik kemudian diolah dengan uji statistik menggunakan perhitungan metode korelasi dengan bantuan SPSS seri IBM versi 22.

\section{HASIL DAN PEMBAHASAN}

Penelitian ini dilakukan terhadap 110 sampel di RSUD Budhi Asih. Sampel merupakan pasien Stroke iskemik fase akut yang melakukan pemeriksaan D-dimer dan LDL kolesterol pada waktu yang sama periode Januari 2017-Desember 2018. Pasien Stroke iskemik fase akut ditentukan berdasarkan diagnosis dokter yang tercatat pada rekam medis.

Hasil penelitian terhadap kadar D-dimer dan kadar LDL pada pasien Stroke iskemik fase akut yang diperoleh dari hasil pemeriksaan di laboratorium RSUD Budhi Asih dapat dilihat pada Tabel 1.

Tabel 1.

Hasil pemeriksaan pada penderita Stroke iskemik Di RSUD Budhi Asih tahun 2017-2018 berdasarkan jenis kelamin

\begin{tabular}{ccc}
\hline Jenis kelamin & Jumlah & \% \\
\hline Pria & 62 & 56,4 \\
\hline Wanita & 48 & 43,6 \\
\hline
\end{tabular}

Berdasarkan Tabel 1, hasil pemeriksaan pada pasien Stroke iskemik terhadap 110 sampel pasien, didapatkan hasil jenis kelamin pria sebanyak 62 orang $(56,4 \%)$ dan wanita sebanyak 48 orang $(43,6 \%)$

Tabel 2.

Hasil pemeriksaan pada penderita Stroke iskemik Di RSUD Budhi Asih tahun 2017-2018 berdasarkan kelompok usia

\begin{tabular}{ccccc}
\hline Usia & Pria & Wanita & Jumlah & \% \\
\hline $25-34$ & 1 & 1 & 2 & 1,8 \\
$35-44$ & 3 & 3 & 6 & 5,5 \\
$45-54$ & 15 & 15 & 30 & 27,3 \\
$55-64$ & 25 & 14 & 39 & 35,5 \\
$65-74$ & 18 & 9 & 27 & 24,5 \\
$>74$ & 2 & 4 & 6 & 5,5 \\
\hline Jumlah & 64 & 46 & 110 & $100 \%$ \\
\hline
\end{tabular}

Sumber penggolongan usia : (Kemenkes RI, 2018) 
Berdasarkan Tabel 2, didapatkan faktor usia paling berisiko tinggi pada usia 55-64 tahun sebanyak 39 orang $(35,5 \%)$ dengan jumlah pria sebanyak 25 orang dan wanita sebanyak 14 orang, sedangkan faktor usia berisiko rendah pada usia 25-34 tahun sebanyak 2 orang $(1,8 \%)$ dengan jumlah pria sebanyak 1 orang dan wanita sebanyak 1 orang.

Tabel 3.

Hasil pemeriksaan D-dimer dan LDL kolesterol pada penderita Stroke iskemik di RSUD Budhi Asih tahun 2017-2018 berdasarkan nilai normal

\begin{tabular}{ccccc}
\hline & & \multicolumn{2}{c}{ Kadar LDL } & \multirow{2}{*}{ Total } \\
\cline { 3 - 4 } & & Normal & Abnormal & \\
\hline Kadar D-dimer & Normal & 17 & 8 & 25 \\
Abnormal & & 17 & 68 & 85 \\
Total & & 34 & 76 & 110 \\
\cline { 2 - 4 } & & & &
\end{tabular}

Berdasarkan Tabel 3, didapatkan bahwa pada penderita Stroke iskemik yang memiliki kadar LDL abnormal sebanyak 76 orang (69\%), sedangkan D-dimer abnormal sebanyak 85 orang (77\%). Pada penderita Stroke iskemik yang memiliki kadar LDL normal sebanyak 34 orang (31\%), sedangkan Ddimer normal sebanyak 25 orang (23\%).

Tabel 4.

Hasil pemeriksaan LDL kolesterol pada penderita Stroke iskemik di RSUD Budhi Asih tahun 2017-2018 berdasarkan jenis kelamin, kelompok usia dan nilai normal

\begin{tabular}{ccccc}
\hline Usia & \multicolumn{2}{c}{ LDL Normal } & \multicolumn{2}{c}{ LDL Abnormal } \\
\cline { 2 - 5 } & $\begin{array}{c}\text { Pria } \\
(\boldsymbol{\%})\end{array}$ & $\begin{array}{c}\text { Wanita } \\
(\boldsymbol{\%})\end{array}$ & $\begin{array}{c}\text { Pria } \\
(\boldsymbol{\%})\end{array}$ & $\begin{array}{c}\text { Wanita } \\
(\boldsymbol{\%})\end{array}$ \\
\hline $25-34$ & $1(2,9 \%)$ & $1(2,9 \%)$ & 0 & $1(1,3 \%)$ \\
$35-44$ & $2(5,9 \%)$ & $1(2,9 \%)$ & $1(1,3 \%)$ & $2(2,6 \%)$ \\
$45-54$ & $4(11,8 \%)$ & $4(11,8 \%)$ & $10(13,2 \%)$ & $12(15,8 \%)$ \\
$55-64$ & $6(17,6 \%)$ & $9(26,5 \%)$ & $17(22,4 \%)$ & $6(7,9 \%)$ \\
$65-74$ & $5(14,7 \%)$ & $1(2,9 \%)$ & $14(18,4 \%)$ & $7(9,2 \%)$ \\
$>74$ & 0 & 0 & $2(2,6 \%)$ & $4(5,3 \%)$ \\
\hline & & & & \\
Jumlah & $18(52,9 \%)$ & $16(47,1 \%)$ & $44(57,9 \%)$ & $32(42,1 \%)$ \\
\hline
\end{tabular}

Berdasarkan Tabel 4, didapatkan hasil LDL normal pada pria berjumlah 18 orang $(52,9 \%)$ dan pada wanita berjumlah 16 orang $(47,1 \%)$. Sedangkan hasil LDL abnormal pada pria berjumlah 44 orang $(57,9 \%)$ dan pada wanita berjumlah 32 orang $(42,1 \%)$. 
Tabel 5.

Hasil pemeriksaan kadar D-dimer pada penderita Stroke iskemik di RSUD Budhi Asih tahun 2017-2018 berdasarkan jenis kelamin, kelompok usia dan nilai normal

\begin{tabular}{ccccc}
\hline Usia & \multicolumn{2}{c}{ D-dimer Normal } & \multicolumn{2}{c}{ D-dimer Abnormal } \\
\cline { 2 - 5 } & $\begin{array}{c}\text { Pria } \\
(\boldsymbol{\%})\end{array}$ & $\begin{array}{c}\text { Wanita } \\
(\boldsymbol{\%})\end{array}$ & $\begin{array}{c}\text { Pria } \\
(\boldsymbol{\%})\end{array}$ & $\begin{array}{c}\text { Wanita } \\
(\boldsymbol{\%})\end{array}$ \\
\hline $25-34$ & $1(4 \%)$ & $1(4 \%)$ & 0 & 0 \\
$35-44$ & $2(8 \%)$ & 0 & $1(1,2 \%)$ & $3(3,5 \%)$ \\
$45-54$ & $2(8 \%)$ & $4(16 \%)$ & $12(14,1 \%)$ & $12(14,1 \%)$ \\
$55-64$ & $2(8 \%)$ & $6(24 \%)$ & $22(25,8 \%)$ & $10(11,8 \%)$ \\
$65-74$ & $5(20 \%)$ & $2(8 \%)$ & $13(15,3 \%)$ & $6(7,1 \%)$ \\
$>74$ & 0 & 0 & $2(2,4 \%)$ & $4(4,7 \%)$ \\
\hline Jumlah & $12(48 \%)$ & $13(52 \%)$ & $50(58,8 \%)$ & $35(41,2 \%)$ \\
\hline
\end{tabular}

Berdasarkan Tabel 5, didapatkan hasil D-dimer normal pada pria berjumlah 12 orang (48\%) dan pada wanita berjumlah 13 orang (52\%). Sedangkan hasil D-dimer abnormal pada pria berjumlah 50 orang $(58,8 \%)$ dan pada wanita berjumlah 35 orang $(41,2 \%)$.

Tabel 6.

Hubungan nilai D-dimer dan LDL kolesterol pada penderita Stroke iskemik di RSUD Budhi Asih tahun 2017-2018

\begin{tabular}{ccc}
\hline Variabel Yang Diuji & $\begin{array}{c}\text { P-value (Signifikasi } \\
\mathbf{p}<\mathbf{0 , 0 5})\end{array}$ & Nilai r \\
\hline D-dimer & 0,000 & 0,840 \\
\hline LDL kolesterol & 0,000 & 0,840 \\
\hline
\end{tabular}

Dalam penelitian ini hasil analisis data pada uji normalitas dilakukan dengan menghitung hasil Skewness dan didapatkan hasil 1,247 (<2) maka disimpulkan bahwa distribusi data normal. Penilaian hubungan antar variabel dengan sebaran data normal digunakan uji statistik analisis korelasi Pearson. Digunakan tingkat kepercayaan (Confidence Interval/CI) 95\%, tingkat signifikansi $(\alpha)$ 0,05 dan perbedaan statistik bermakna bila $\mathrm{p}<0,05$.

Berdasarkan Tabel 6, dilakukan uji korelasi dan didapatkan hasil analisis yaitu dengan nilai signifikasi 0,000 $(\mathrm{p}<0,05)$, hal ini menyatakan terdapat hubungan antara kadar LDL kolesterol dengan kadar D-dimer pada pasien Stroke iskemik. Nilai r pada penelitian ini sebesar 0,840 yang menyatakan adanya korelasi positif yang sangat kuat antara LDL kolesterol dengan D-dimer, dimana setiap kenaikan kadar LDL kolesterol diikuti dengan kenaikan kadar D-dimer pada pasien Stroke iskemik. 
Dari hasil penelitian, yang melakukan pemeriksaan D-dimer dan LDL kolesterol pada penderita Stroke iskemik di RSUD Budhi Asih tahun 2017-2018 didapatkan sampel 110 kasus. Pada Tabel 1, didapatkan hasil pemeriksaan pada pasien Stroke iskemik berdasarkan jenis kelamin, didapatkan pada pria sebanyak 62 orang $(56,4 \%)$ dan wanita sebanyak 48 orang $(43,6 \%)$. Pada kejadian ini Stroke lebih banyak dialami oleh pria dibandingkan wanita, karena wanita terlindungi secara hormonal. Didukung oleh teori (Marcelina, Siagian, \& Tarigan, 2016) wanita lebih terlindungi dari penyakit jantung dan Stroke sampai umur pertengahan akibat hormon estrogen yang dimilikinya. Setelah menopause risiko wanita sama dengan pria untuk terkena serangan Stroke dan penyakit jantung. Namun teori (Handayani, 2012) mengatakan perbedaan serangan stroke pada laki-laki dan wanita bukan karena semata-mata disebabkan hormon seksual. Mekanisme kematian sel juga berkaitan dengan penatalaksanaan yang diberikan. Meskipun pada wanita ada perlindungan dari hormon seksual terhadap serangan stroke, namun tidak menunjukan perbedaan respon terhadap terapi farmakologis untuk mencegah penyakit vaskuler. Pathway metabolisme antara estrogen yang aktif dan tidak aktif, efek terhadap fungsi pembekuan darah, mitokondria, proses inflamasi dan angiogenesis harus diteliti secara mendalam untuk menjawab peranan estrogen pada wanita dalam melindungi terhadap serangan stroke. Efek komponen genomic dan non-genomik juga berkaitan dengan proses-proses perlindungan terhadap serangan stroke. Aufa (2014) mendapatkan proporsi Stroke dari 56 pasien di RSUD dr. Zainoel Abidin Banda Aceh sebanyak 31 pasien pria (55,3\%) dan 25 pasien wanita (44,6\%). Hal yang sama juga dijumpai Neysa (2015) pada penelitiannya mendapatkan pria lebih dominan dibandingkan wanita, dengan persentasi $67,2 \%$ dengan $32,8 \%$.

Berdasarkan Tabel 2, didapatkan faktor usia paling berisiko tinggi pada usia 55-64 tahun sebanyak 39 orang $(35,5 \%)$ dengan jumlah pria sebanyak 25 orang dan wanita sebanyak 14 orang sedangkan faktor usia berisiko rendah pada usia 25-34 tahun sebanyak 2 orang $(1,8 \%)$ dengan jumlah pria sebanyak 1 orang dan wanita sebanyak 1 orang. Peningkatan frekuensi stroke seiring dengan peningkatan umur berhubungan dengan proses penuaan, dimana semua organ tubuh mengalami kemunduran fungsi termasuk pembuluh darah otak. Pembuluh darah menjadi tidak elastis terutama bagian endotel yang mengalami penebalan pada bagian intima, sehingga mengakibatkan lumen pembuluh darah semakin sempit dan berdampak pada penurunan aliran darah otak. Hal ini sejalan dengan teori (Badrul Munir, 
Harun Al Rasyid, 2015) Usia merupakan salah satu faktor risiko utama stroke, insiden stroke meningkat hampir 2 kali lipat setelah melewati usia 55 tahun. Hal ini karena semakin banyak stress oksidatif dan semakin luas proses aterosklerosis yang terjadi sehingga melemahnya fungsi tubuh secara menyeluruh terutama terkait dengan fleksibilitas pembuluh darah. Hasil penelitian ini sejalan dengan penelitian (Sofyan, Sihombing, \& Hamra, 2013) yang mendapatkan bahwa persentasi kelompok umur $>55$ tahun lebih banyak menderita stroke dibandingkan dengan kelompok umur $<55$ tahun. Stroke yang menyerang kelompok usia diatas 40 tahun adalah kelainan otak nontraumatik akibat proses patologi pada sistem pembuluh darah otak. Penelitian (Lf Nasution, 2014) juga mendapatkan hasil laki-laki lebih banyak menderita stroke pada usia diatas 40 tahun dengan riwayat hipertensi yang merupakan salah satu faktor risiko terjadinya Stroke iskemik.

Berdasarkan Tabel 3, didapatkan 34 kasus (31\%) kadar LDL normal, dengan D-dimer normal sebanyak 25 kasus (23\%). Sedangkan kadar LDL abnormal terdapat 76 kasus (69\%) dengan D-dimer abnormal sebanyak 85 kasus (77\%). Berdasarkan hasil penelitian ini, dianalisis kadar LDL >100 mg/dl diasumsikan terjadinya penyumbatan arteri melalui pembentukan ateroma yang dapat menjadi faktor risiko Stroke iskemik. Sedangkan kadar D-dimer $>300 \mathrm{ng} / \mathrm{mL}(0,3 \mathrm{mg} / \mathrm{L})$ mengindikasikan terbentuknya degradasi fibrin akibat pemecahan trombus yang dapat menjadi marker terjadinya Stroke iskemik. Teori (Badrul Munir, Harun Al Rasyid, 2015) menyebutkan kadar LDL berlebih dapat menumpuk di bagian dalam dinding arteri yang memasok organ tubuh dengan oksigen dan nutrisi. Penumpukan LDL ini dapat mempersempit dan menyumbat arteri melalui pembentukan ateroma. Pemeriksaan kadar D-dimer dapat digunakan untuk mendiagnosis adanya penyumbatan yang dilanjutkan dengan proses fibrinolisis. Data ini sesuai dengan hasil penelitian yang dilakukan oleh (Sunartejo, 2012) kejadian stroke iskemik pada kondisi LDL-Kolesterol normal sebesar 33,3\% dan pada LDL-Kolesterol tinggi sebesar 66,6\%. Hal ini juga sesuai dengan penelitian sebelumnya yang menyatakan bahwa kadar D-dimer yang meningkat menunjukan terbentuk trombus, tetapi tidak dapat menunjukan lokasi kelainan.

Berdasarkan Tabel 4, didapatkan hasil LDL normal pada pria berjumlah 18 orang $(52,9 \%)$ dan pada wanita berjumlah 16 orang $(47,1 \%)$. Sedangkan hasil LDL abnormal pada pria berjumlah 44 orang $(57,9 \%)$ dan pada wanita berjumlah 32 orang $(42,1 \%)$. Pada penelitian ini didapatkan kadar LDL pria 
lebih tinggi dibanding wanita hal ini mungkin disebabkan karena perempuan dalam fase premenopause, sehingga mempunyai efek proteksi dari hormon estrogen terhadap kadar kolesterol darah yang akan memberikan efek LDL yang rendah. Teori (Patricia et al., 2015) LDL membawa kolesterol dari hati ke sel-sel. Jika kadarnya tinggi akan mengakibatkan terjadinya penumpukan kolesterol di dinding pembuluh darah dan memicu terjadinya pengerasan dinding pembuluh darah yang berujung pada aterosklerosis. Plak terlepas dan menyebabkan stroke. Namun teori (Zeljkovic et al., 2010) menyebutkan Partikel small, dense low-density lipoprotein (sdLDL) dan low-density lipoprotein (HDL) berukuran kecil merupakan salah satu faktor risiko, tetapi untuk signifikansi klinis stroke iskemik akut (AIS) masih belum pasti, sehingga sering didapatkan kadar LDL yang masih dalam batas nilai normal.

Berdasarkan Tabel 5, didapatkan hasil D-dimer normal pada pria berjumlah 12 orang (48\%) dan pada wanita berjumlah 13 orang (52\%). Sedangkan hasil D-dimer abnormal pada pria berjumlah 50 orang $(58,8 \%)$ dan pada wanita berjumlah 35 orang $(41,2 \%)$. Pada penelitian ini didapatkan peningkatan kadar D-dimer pada subjek yang lebih tua disebabkan pada subjek yang berusia tua mengalami penurunan elastisitas pembuluh darah. Hilangnya elastisitas pembuluh darah yang ditambah dengan timbunan lemak darah dan proses degeneratif pada usia tua, akan menyebabkan gangguan hemoreologi, aktivasi trombosit dan faktor-faktor koagulasi yang dapat meningkatkan proses terjadinya pembentukan trombus.

Berdasarkan Tabel 6, dilakukan uji korelasi didapatkan hasil analisis yaitu signifikasi $0,000(\mathrm{p}<0,05)$ dengan nilai korelasi 0,840 yang dinyatakan terdapat hubungan yang sangat kuat antara kadar LDL dengan kadar D-dimer pada penderita Stroke iskemik. Menurut teori (Widjaja, 2010), adanya aterosklerosis akibat penimbunan berbagai komponen termasuk lipid di otak mendominasi untuk terjadinya suatu emboli yang akan menyumbat dan menyebabkan Stroke iskemik. Hasil D-dimer yang meningkat akan mengindikasikan adanya proses fibrinolisis, tetapi tidak menunjukan lokasi kelainan. Hal ini sejalan dengan penelitian yang dilakukan oleh (Cut Diana Maya Theresa, Yuneldi Anwar, 2014) dimana dijumpai hasil analisa statistik menggunakan uji korelasi Spearman menunjukkan bahwa korelasi antara kadar kolestrol LDL dengan kejadian stroke adalah bermakna $(\mathrm{p}=0.030)$. 


\section{SIMPULAN}

Terdapat hubungan yang signifikan ( $\mathrm{p}$-value $=0,000$ ) dengan nilai $\mathrm{r}$ sebesar 0,840 yang menyatakan adanya korelasi positif yang sangat kuat antara kadar LDL kolesterol dengan kadar D-dimer pada pasien Stroke iskemik di RSUD Budhi Asih Jakarta Timur. Sebagian besar penderita Stroke iskemik di RSUD Budhi Asih berjenis kelamin laki-laki yaitu sebanyak 62 orang $(56,4 \%)$ pada periode Januari 2017-Desember 2018. Berdasarkan kelompok usia penderita Stroke iskemik di RSUD Budhi Asih faktor usia paling berisiko tinggi pada usia 55-64 tahun sebanyak 39 orang (35,5\%). Pada pasien Stroke iskemik berdasarkan nilai normal kadar LDL dan D-dimer didapatkan hasil kadar LDL abnormal sebanyak 76 orang (69\%) dengan D-dimer abnormal sebanyak 85 orang (77\%), sedangkan kadar LDL normal sebanyak 34 orang (31\%) dengan D-dimer normal sebanyak 25 orang (23\%).

\section{UCAPAN TERIMA KASIH}

Penulis mengucapkan terima kasih kepada Prodi D III Analis Kesehatan Universitas MH Thamrin berperan serta dalam penelitian ini.

\section{DAFTAR PUSTAKA}

1. Agusti, N. I., Yacob, T., \& Fridayenti. (2014). Profil Rasio Kolesterol LDL dan HDL Pada Pasien Stroke Di Bagian Saraf RSUD Arifin Achmad Provinsil Riau Periode Januari Sampai Desember 2012. 1(2), 1-15.

2. Anggriani, A., Zulkarnain, Z., Sulaiman, S., \& Gunawan, R. (2018). Pengaruh ROM (Range of Motion) Terhadap Kekuatan Otot Ekstremitas Pada Pasien Stroke Non Hemoragic. Jurnal Riset Hesti Medan Akper Kesdam I/BB Medan, 3(2), 64.

3. Arifianto, A. S., Sarosa, M., \& Setyawati, O. (2014). Klasifikasi Stroke Berdasarkan Kelainan Patologis dengan Learning Vector Quantization. Klasifikasi Stroke Berdasrkan Kelainan Patologis Dengan Vector Quantizition, 8(2), 117-122.

4. Badrul Munir, Harun Al Rasyid, R. R. (2015). Hubungan Antara Kadar Glukosa Darah Acak Pada Saat Masuk Instalasi Gawat Darurat Dengan Hasil Keluaran Klinis Penderita Stroke Iskemik Fase Akut Relationship. 52-60.

5. Cut Diana Maya Theresa, Yuneldi Anwar, A. K. (2014). Hubungan antara kadar lipoprotein dengan kejadian stroke dan tumor otak. Majalah Kedokteran Nusantara The Journal Of Medical School, 47(3), 133-136.

6. Darmawaty, Arif, M., Pakasi, R., Hardjoeno, Bahar, B., \& Muis, A. (2011). Hubungan Kadar Ddimer dengan Skor Canadian Neurological Scale (CNS) Pada Penderita Stroke Iskemik Akut.

7. Dinata, C. A., Safrita, Y., \& Sastri, S. (2013). Gambaran Faktor Risiko dan Tipe Stroke pada 
Pasien Rawat Inap di Bagian Penyakit Dalam RSUD Kabupaten Solok Selatan Periode 1 Januari 2010 - 31 Juni 2012. Jurnal Kesehatan Andalas.

8. Efrimaisa, A. N. (2015). Peranan Obesitas Pada Stroke Iskemik Akut. Banda Aceh. Universitas Syiah Kuala.

9. Handayani, F. (2012). Angka Kejadian Serangan Stroke Pada Wanita Lebih Rendah Daripada Laki-Laki. Keperawatan Medikal Bedah.

10. Hasibuan, A. E., Fitri, A., Surbakti, K. P., \& Rambe, A. S. (2015). Hubungan Kadar Low-Density Lipoprotein Cholesterol dengan Kejadian dan Keparahan Stroke Akut. Neurona, 32(3), 1-8.

11. Hermawan, Y. (2013). Hubungan Derajat Aktivitas Fisik pada Laki-laki dengan Kejadian Stroke Iskemik di RSUD DR. Moewardi Surakarta. Universitas Sebelas Maret. 6-20.

12. Hutagalung, MS. (2014). Panduan Lengkap Stroke Mencegah, Mengobati dan Menyembuhkan. Nusa Media.

13. Irsyada, A. (2014). Perbandingan Lipid Protein Pada Pasien Stroke Hemoragik dan Stroke Iskemik DI RSUDZA Banda Aceh. Banda Aceh. Universitas Syiah Kuala.

14. Kemenkes RI. (2018). Hasil Utama Riset Kesehatan Dasar Tahun 2018. Kementrian Kesehatan Republik Indonesia, 1-100. Latifah, L. (2016). Pemenuhan Kebutuhan Activities of Daily Living (Adl) Pasien Stroke Oleh Perawat Di Rumah Sakit Pku Muhammadiyah Yogyakarta Dan Gamping. $10-25$.

15. Marcelina, H., Siagian, L. O., \& Tarigan, J. (2016). Gambaran Tekanan Darah Pada Penderita Stroke yang Di Rawat Inap di Rumah Sakit Tk II Putri Hijau Kesdam I / BB Medan Tahun 2016. 2016-2019.

16. Mayke, Y. (2013). Kadar D-dimer Plasma Sebagai Parameter Diagnostik Stroke Iskemik Akut Di RSUP H. Adam Malik Medan.

17. Mayke, Y., Aman, A. K., \& Anwar, Y. (2018). Kadar D-dimer Plasma pada Pasien Stroke Iskemik Akut. Indonesian Journal Of Clinical Pathology And Medical Laboratory.

18. Nasution, LF. (2013). Stroke Hemoragik Pada Laki-Laki Usia 65 Tahun. Medula.

19. Patricia, H., Kembuan, M. A. H. N., \& Tumboimbela, M. J. (2015). Karakteristik Penderita Stroke Iskemik Yang Di Rawat Di RSUP Prof. DR. R. D. Kandou Manado. Kandidat Skripsi Fakultas Kedokteran Universitas Sam Ratulangi Manado Berdasarkan definisi WHO ( World Health Organization ) stroke adalah manifestasi klin. Jurnal E-Clinic (ECl), 3(1), 445-451.

20. Pinzon, R., \& Asanti, L. (2010). AWAS STROKE! Pengertian, Gejala, Tindakan, Perawatan dan Pencegahan. Andi.

21. Priambodo, B. (2012). Laporan Hasil Perbandingan Pemberian Heparin Subkutan dan Intravena Terhadap Kadar D-dimer pada Pencegahan Deep Vein Thrombosis. Universitas Dipenogoro.

22. RISKESDAS. (2013). Jakarta: Badan Penelitian dan Pengembangan Kesehatan Departemen Kesehatan Republik Indonesia. Jakarta: Badan Penelitian Dan Pengembangan Kesehatan Departemen Kesehatan Republik Indonesia, (Penyakit Menular), 103.

23. Rosandi, R. (2014). Korelasi Kadar D-dimer dengan Derajat Keparahan dan Lama Sakit Pasien 
Urtikaria Kronis, Ridha Rosandi, FK UI, 2014. (November).

24. Saribanon, S. (2011). Hubungan Kadar LDL Kolesterol dengan Moralitas Pasien Stroke Iskemik Fase Akut di RSUD DR. Moewardi Surakarta. Universitas Sebelas Maret. 5-21.

25. Soebroto, L. (2010). Hubungan Antara Kadar LDL Kolesterol pada Penderia Stroke di Rumah Sakit Dr. Moewardi Surakarta. 51.

26. Sofyan, A. M., Sihombing, I. Y., \& Hamra, Y. (2013). Hubungan Umur, Jenis Kelamin, dan Hipertensi dengan Kejadian Stroke. Medula, 1(1), 24-30.

27. Sunartejo, T. (2012). HUBUNGAN HIPERURISEMIA DENGAN ANGKA KEJADIAN STROKE ISKEMIK DI RSUD Dr. MOEWARDI., 10(9), 32.

28. T. Wongso, Dewi LS, Z. L. (2015). Clinical Pathology and Majalah Patologi Klinik Indonesia dan Laboratorium Medik. Jurnal Indonesia, 21(3), 261-265.

29. Wayunah, W., \& Saefulloh, M. (2018). Analisis Faktor Yang Berhubungan Dengan Kejadian Stroke Di Rsud Indramayu. Jurnal Pendidikan Keperawatan Indonesia, 2(2), 65.

30. Wicaksono, S. A. (2017). Pengaruh Pemberian Heparin Subkutan Sebagai Profilaksis Trombosis Vena dalam (TVD) Terhadap Nilai D-dimer Pda Psien Sakit Kritis Di ICU RSUP DR. Kariadi. Universitas Diponegoro. 2(April), 31-38.

31. Widjaja, A. C. (2010). Uji Diagnostik Pemeriksaan Kadar D-dimer Plasma Pada Diagnosis Stroke Iskemik Diagnostic Test Of Plasma D-dimer Assay.

32. Zeljkovic A Zeljkovic A, Vekic J, Spasojevic-Kalimanovska V, Jelic-Ivanovic Z, BogavacStanojevic N, Gulan B, Spasic S. (2010). LDL and HDL subclasses in acute ischemic stroke: prediction of risk and short-term mortality.US National Library of Medicine. 